\author{
Barbara Brzezicka \\ Uniwersytet Gdański \\ barbara.brzezicka@ug.edu.pl \\ ORCID: 0000-0002-6387-3250
}

\title{
POCZĄTKI PRZEKŁADU FILOZOFICZNEGO W POLSCE
}

DOI: http://dx.doi.org/10.12775/RP.2021.002

\begin{abstract}
Zarys treści: Artykuł stanowi próbę przedstawienia jednych z najstarszych polskich przekładów filozoficznych z wykorzystaniem metody zaproponowanej przez Lievena D'hulsta w Essais d'histoire de la traduction. Avatars de Janus. Na wstępie przedmiot badania umieszczony zostaje w kontekście historycznych badań przekładoznawczych. Następnie przedstawione zostają pierwsze polskie tłumaczenia Arystotelesa i Cycerona. Zgodnie z wytycznymi D’hulsta opracowanie stawia na równi takie elementy jak postaci tłumaczy, kontekst powstania czy strategie translatorskie. W ramach podsumowania autorka stara się krótko odpowiedzieć na pytanie o wpływ omawianych przekładów na polskich odbiorców.
\end{abstract}

Słowa kluczowe: przekład filozoficzny, historia przekładu, Cyceron, Arystoteles, XVI wiek, XVII wiek

eden z najwybitniejszych francuskojęzycznych badaczy przekładu, Jean-René Ladmiral, w wystąpieniu zatytułowanym Le tournant philosophique dans la traduction (Zwrot filozoficzny w przekładzie, 2017) wspomniał również o tournant historique, zwrocie historycznym, który można było zaobserwować w ostatniej dekadzie we Francji i krajach francuskojęzycznych. Ladmiral miał zapewne na myśli m.in. wydawaną od 2012 roku czterotomową Histoire des traductions en langue française, a także inne publikacje i wydarzenia naukowe poświęcone historii przekładu. W przestrzeni anglojęzycznej odpowiednikiem Histoire des traductions en langue française jest Oxford History of Literary Translation in English, rozpoczęta w 2005 roku i dotąd nieukończona. Obie publikacje opierają się na tradycyjnym 
podziale historycznoliterackim obowiązującym odpowiednio we Francji i w Wielkiej Brytanii (Chevrel, D’hulst, Lombez 2012: 9; Reynolds 2018: 8). Poza tym badacze i badaczki podejmowali temat historii przekładów, stosując rozmaite metody przekrojowe, takie jak perspektywa roli tłumaczy i tłumaczek w klasycznej już pozycji Jeana Delisle’a i Judith Woodsworth Translators through history czy niedawno opublikowana Histoire naturelle de la traduction Charles'a Le Blanca, który podejmuje temat historyczności przekładów za pomocą metafor zaczerpniętych z baśni i innych kanonicznych tekstów literackich (Le Blanc 2019). Czy faktycznie można mówić o zwrocie historycznym w badaniach przekładoznawczych? Być może to sformułowanie jest nieco przesadzone, jednak statystyki przytaczane przez Lievena D'hulsta potwierdzają rosnącą popularność podejścia historycznego (approche historique). Według Translation Studies Bibliography w latach 1994-2012 opublikowano 1223 prace z perspektywy historycznej, którą wyprzedzają jedynie badania literaturo- i kulturoznawcze. Co być może zaskakujące z polskiego punktu widzenia, badania historyczne były dwukrotnie liczniejsze niż badania językoznawcze uwzględnione w tej bazie (D’hulst 2014: 7). W roku 2019 według tej samej bazy zostały wydane 1752 publikacje zawierające słowo kluczowe history.

W Polsce perspektywa historyczna obecna jest przede wszystkim w badaniach nad przekładem literackim (Balcerzan 1984, Legeżyńska 1986, Soliński 1987, Sadkowski 2013 i inne), w mniejszym stopniu w badaniach nad tekstami nieliterackimi. W niniejszym artykule chciałabym podjąć próbę zastosowania podejścia historycznego do tekstów filozoficznych, wzorując się na autorach i autorkach Histoire des traductions en langue française, którzy starali się przedstawić nie tylko świat literatury, ale też różne „dziedziny życia umysłowego" (domaines de la "vie de l'esprit"), takie jak nauka, religia, filozofia, prawo czy historia (Chevrel, D’hulst, Lombez 2012: 9). Teksty filozoficzne, obok tekstów prawnych i poradników ${ }^{1}$, stanowią jedne z pierwszych przekładów nieliterackich spoza domeny religijnej. Szesnastowieczne przekłady często cechowała pewna swoboda z perspektywy dzisiejszej tłumaczki tekstów nieliterackich, jednak były to teksty o znacznie większym stopniu wierności niż popularne wówczas adaptacje, takie jak Dworzanin polski Łukasza Górnickiego, inspirowany Il Cortegiano Baldassare’a Castiglionego

1 Drobiazgową analizę polskiego przekładu jednego $\mathrm{z}$ takich dzieł, poradnika Piotra Krescencjusza, przedstawia Joanna Kamper-Warejko (2017). 
(Ziomek 1995: 380), czy Senatulus, czyli Sejm niewieści Andrzeja Glabera, inspirowany twórczością Erazma z Rotterdamu. Glaber był również autorem przekładów filozoficznych, takich jak Xięgi, które zowia język, z łacińskiego na polski wyłożony Erazma z Rotterdamu, Gadki o składności człowieczych członków, będące tłumaczeniem czy też raczej adaptacją przypisywanego wówczas Arystotelesowi apokryfu, oraz Żywoty filozofów napisane oryginalnie po łacinie przez Waltera Burlacusa, ale tłumaczone przez Glabera i Marcina Bielskiego z wersji czeskiej (Sadkowski 2013: 14).

Przedmiotem badania są wybrane teksty spośród pierwszych polskich przekładów dwóch klasycznych twórców filozofii starożytnej: Cycerona i Arystotelesa. Oprócz pseudoarystotelesowskiej Ekonomiki wszystkie do dziś należą do kanonu tekstów filozoficznych. Obecnie Ekonomiki nie uznaje się za dzieło Arystotelesa (Skrzydlewski 2010: 1), jednak w okresie powstania przekładu należała ona do corpus Aristotelicum, co pozwala uwzględnić ten tekst $\mathrm{w}$ badaniu historycznym zgodnie $\mathrm{z}$ zasadą postulowaną przez Anthony'ego Pyma, według której historia przekładu powinna obejmować wszystkie teksty uznawane niegdyś za przekłady w kulturze docelowej (Pym 1998: 60). W przypadku Ekonomiki nie mamy do czynienia z pseudoprzekładem, jednak uwzględnienie tego tekstu wydaje się zgodne $\mathrm{z}$ duchem wytycznych Pyma, zwłaszcza że omawiane teksty łączy też tematyka, dzięki czemu łatwiej jest porównać stosowane przez tłumaczy terminy filozoficzne. Sześć tekstów, wydanych w latach 1575-1618, przedstawionych zostanie zgodnie z wytycznymi zaproponowanymi przez Lievena D’hulsta, jednego $\mathrm{z}$ redaktorów pierwszego opublikowanego tomu Histoire des traductions en langue française (2014: 28-41). Swój „program historyczny” zarysowuje on za pomocą ośmiu prostych pytań: Quis? Quid? Ubi? Quibus auxiliis? Cur? Quomodo? Quando? Cui bono?, czyli: Kto? Co? Gdzie? Z czyją pomocą? Dlaczego? Jak? Kiedy? Na czyją korzyść? Ostatnie pytanie dotyczy rezultatów działalności przekładowej, czytelników, do których dotarł przekład, i jego wpływu na kształtowanie kultury (D’hulst 2014: 28-41).

Propozycja programowa D’hulsta może na pierwszy rzut oka wydawać się banalna, jednak jej prostota pozwala przełamać dychotomię między pierwszeństwem tekstów w tradycyjnych badaniach przekładoznawczych a pierwszeństwem tłumaczy postulowanym np. przez Anthony'ego Pyma $(1998,2009)$ czy przez Andrew Chestermana $(2009)^{2}$. O ile w Translator Stu-

2 Na gruncie polskim podobne podejście można zaobserwować np. w tekście Jerzego 
dies Chestermana historia jest jednym z elementów wymiaru kulturowego, który wraz z wymiarem kognitywnym i społecznym stanowią podstawowe dziedziny badań nad tłumaczami (Chesterman 2009: 19), o tyle dla D’hulsta osoba tłumacza jest jednym z elementów badań historycznych. Anthony Pym czyni z osoby tłumacza centralny przedmiot badania historycznego (Pym 1998: ix) i mówi: „Study translators, then texts” (Pym 2009: 30), tymczasem D’hulst stawia pytania Quis? Quomodo? i Quid? na równi z innymi - żadna $\mathrm{z}$ tych perspektyw nie jest dla niego bardziej fundamentalna niż inne. Wytyczne D’hulsta nie są jednak sprzeczne z programem postulowanym przez Pyma, który w swoich tekstach historiograficznych odpowiada na te same pytania, różnicując jedynie ich wagę i organizując prezentację tematu w nieco inny sposób (Pym 1998: 5-7). Oczywiście, ten banalny na pozór program nie jest wcale banalny w realizacji i nie zawsze możliwa jest odpowiedź na wszystkie pytania, jednak pozwalają one w prosty sposób uporządkować elementy kontekstu historycznego.

\section{Quis? Ubi?}

Kim byli pierwsi tłumacze tekstów filozoficznych i gdzie pracowali nad swoimi przekładami? Stanisław Koszutski (zm. 1559), tłumacz O powinnościach Cycerona, był królewskim bibliotekarzem i sekretarzem, a także pisarzem. Spod jego pióra wyszły m.in. Księgi o wychowaniu i o ćwiczeniu każdego przełożonego, będące adaptacją dzieła Reinhardta Lorichiusa (Ziomek 1995: 243-244). Nieco mniej wiadomo o Bieniaszu Budnym, tłumaczu Rozmowy o przyjaźni oraz Księgi starości - nieznana jest data jego urodzenia, wiadomo jedynie, że umarł po 1624 roku. Poza przekładami Cycerona Budny dokonał powtórnej przeróbki jednej z nowel Dekameronu Boccaccia (Ziomek 1995: 131), wydał również Krótkie powieści, które zowa Apophtegmata, będące zbiorem historii różnych greckich autorów (Lelewel 1823: 230). Z kolei pierwszy tłumacz Arystotelesa, Sebastian Petrycy (1554-1626), pochodził z Pilzna. Urodził się w zamożnej mieszczańskiej rodzinie i otrzymał typowe w tamtych czasach wykształcenie, którego ukoronowaniem były studia

Święcha Przekłady i autokomentarze (Balcerzan 1984: 45-66). Autor co prawda nie postuluje pierwszeństwa badań nad tłumaczami explicite, jednak to właśnie postać „przekładowcy” oraz wyrażający jego osobiste wybory i preferencje paratekst jest dla Święcha kluczem do badania przekładu oraz kontekstu historycznego, w którym ten przekład powstał. 
medyczne w Padwie. Po powrocie do Polski objął profesurę na Wydziale Sztuk Wyzwolonych w Krakowie, następnie jednak ze względu na trudności z nostryfikacją dyplomu przeniósł się do Lwowa. W okresie, w którym pracował nad tłumaczeniami Arystotelesa, ponownie mieszkał już w Krakowie, lecz „utrzymywał dość luźne związki z Uniwersytetem” (Winiarska 1994: 125). Później wrócił na Wydział Lekarski, jednak jego kariera naznaczona była licznymi konfliktami z Uniwersytetem. Był cenionym wykładowcą, zarówno w dziedzinie literatury starożytnej, jak i nauk ścisłych, co świadczy o szerokich horyzontach tłumacza (Winiarska 1994: 124-125).

\section{Quid? Quando?}

Co i kiedy tłumaczono? Na podstawie dostępnych bibliografii (takich jak bibliografia Estreichera) i katalogów bibliotecznych (przede wszystkim katalogu starodruków Biblioteki Uniwersytetu Jagiellońskiego) można uznać, że najprawdopodobniej pierwszym tekstem z kanonu filozofii przełożonym na język polski było De officiis Marka Tuliusza Cycerona: O powinnościách wszech stanow ludźi dostępne dzisiaj w zbiorach starodruków Biblioteki Jagiellońskiej. Nieznana jest dokładna data jego powstania, gdyż tekst został wydany w 1575 roku, szesnaście lat po śmierci tłumacza, Stanisława Koszutskiego. Można zatem przyjąć, że przekład powstał pod koniec pierwszej połowy XVI wieku. Kolejne zachowane do dzisiaj teksty to Księga starości (Cato Major De Senectute) oraz Rozmowa o przyjaźni (Laelius de Amicitia) - oba teksty autorstwa Cycerona przełożył Bieniasz Budny, a wydane zostały odpowiednio w 1595 i 1603 roku. W tym samym czasie powstały również

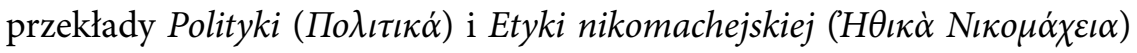

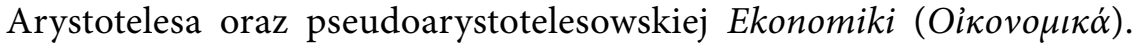
Wszystkie trzy teksty przetłumaczył Sebastian Petrycy w latach 1601-1618. Wnioskując z przypisów tłumacza na marginesach i w dodatkach do kolejnych ksiąg, należy przypuszczać, że przekłady te powstały na podstawie tekstu łacińskiego, nie zaś greckiego oryginału.

Na początku XVII wieku tłumaczono również wielkie dzieła włoskiego renesansu, takie jak Jerozolima wyzwolona Torquata Tassa czy Orland szalony Ludovica Ariosta (Ballard 2013: 136). Niemniej jednak działalność przekładowa w dziedzinie filozofii zdaje się potwierdzać tezę Zenona Klemensiewicza (1985: 239-240), który pisze o wyczerpywaniu się pod koniec XVI 
stulecia „ruchu umysłowego i kulturalnego" polskiego renesansu, o zanikaniu „ambicji kulturalnych” w wyniku ziemiańskiego sposobu życia szlachty, której autor zarzuca wręcz „uwstecznienie”. W podobnym tonie wypowiada się Wacław Sadkowski (2013: 32-40), a także Aleksander Brückner, który o czasach saskich pisał, że były „napiętnowane zastojem politycznym i ekonomicznym, umysłowym i moralnym, literackim i artystycznym" (Brückner 1958: 161). Maria Bogucka podkreśla z kolei niekorzystne zmiany w zakresie czytelnictwa w tej epoce (Bogucka 1991: 193). Szukając polskich tłumaczeń tekstów filozoficznych na język polski, również można zauważyć pewien zastój. Druga połowa XVII i pierwsza połowa XVIII wieku to okres, w którym trudno znaleźć polskie wersje kanonicznych tekstów filozoficznych, a ożywienie następuje dopiero $\mathrm{w}$ drugiej połowie XVIII wieku, kiedy to pojawiają się pierwsze przekłady z języków żywych - m.in. tekstów Voltaire’a (pierwszym tekstem dostępnym w Bibliotece Jagiellońskiej jest Zaira z 1753 roku), Johna Locke’a (począwszy od Książki o edukacji dzieci z 1781 roku) czy Immanuela Kanta (Projekt wieczystego pokoju z 1797 roku).

\section{Quibus auxiliis?}

Kto wspierał tłumaczy w ich działalności? Aż do XIX wieku tłumaczenia powstawały często dzięki mecenatom bogatych książąt, biskupów i magnatów. Świadectwo tego wsparcia można znaleźć na pierwszych kartach wydawanych przekładów, które zawsze poprzedzały podziękowania, a czasem nawet laudacje na cześć mecenasa. Przekład O powinnościach dedykowany jest Mikołajowi Naruszewiczowi, kasztelanowi ziemi żmudzkiej. Co ciekawe, autorem trzystronicowej dedykacji, a także krótkiego wprowadzenia „Do czytelnika” nie jest tłumacz, ale wileński drukarz - Jan Karcan. Nie posiadamy informacji o jego wykształceniu, wiadomo jednak, że miał on „pewne wykształcenie teologiczne”. Nakładem drukarni Karcana, która do 1580 roku działała w Łosku, w Drukarki Zamkowej Jana Kiszki ukazało się w sumie 109 pozycji (Słownik polszczyzny XVI wieku). Karcan wydawał wiele dzieł teologicznych i filozoficznych, takich jak pisma i przekłady Szymona Budnego, w tym słynny przekład Nowego Testamentu $(1574,1578)$, pisma Andrzeja Frycza Modrzewskiego (1577), protestanckiego teologa Marcina Czechowica (1577), a później w Wilnie również kaznodziejów Anzelma Polaka (1595), Andrzeja Wolana (1583, 1593, 1606), a także Piotra Skargi 
(1611) (Topolska 1980: 250). Można zatem przypuszczać, że to z inicjatywy Karcana przekład De officiis ujrzał światło dzienne kilkanaście lat po śmierci tłumacza. Również traktaty O przyjaźni i Księga starości w przekładzie Bieniasza Budnego zostały wydane w drukarni Jana Karcana.

Przekładom Sebastiana Petrycego także towarzyszą obszerne dedykacje i podziękowania. Pierwsze wydanie Polityki z 1605 roku ukazało się nakładem drukarni Szymona Kempiniego w Krakowie i dedykowane jest najpierw królowi Zygmuntowi III Wazie, a następnie kardynałowi Bernardowi Maciejowskiemu, biskupowi Krakowa. Przekłady wydane w 1618 roku ukazały się nakładem krakowskiej drukarni Macieja Jędrzejowczyka. Tym razem Polityka dedykowana była Janowi Zamojskiemu, nazwanemu „Nestorem i Achillesem Polskim”, Etyka arcybiskupowi gnieźnieńskiemu Wawrzyńcowi Gembickiemu, a Ekonomika Mikołajowi Oleśnickiemu, kasztelanowi radomskiemu.

\section{Cur?}

Dlaczego tłumacze zdecydowali się na te, a nie inne teksty? Wybór ten nie jest zaskakujący. Cyceron i Arystoteles, obok takich autorów jak Homer, należą do pisarzy najczęściej tłumaczonych w XVI wieku również w innych krajach (Bellanger 1903: 17). Ponadto, jak pisze Ryszard Palacz (1978: 9), „nie stanowi bynajmniej przesady, jeśli powiemy, że całe nauczanie średniowieczne [filozofii] sprowadzało się do komentowania pism Arystotelesa”. Nic więc dziwnego, że pisma tego filozofa należały do kanonu również w wiekach kolejnych. François Thomas pisze nawet, że tłumaczenia Arystotelesa w XVI wieku można uznać za osobny gatunek (un genre à part) (Duché 2015: 674). Niemal wszystkie wspomniane powyżej teksty (z wyjątkiem Księgi starości, która porusza inną problematykę i zawiera znacznie mniej terminów uznawanych dzisiaj za typowo filozoficzne) dotyczą etyki, rozumianej nie tylko jako zbiór indywidualnych cnót, ale również jako filozofia dobrego życia w rodzinie (ekonomika) i w społeczeństwie obywateli polis (polityka). Warto podkreślić, że jeszcze w XV wieku, np. na Uniwersytecie Krakowskim, nauczanie etyki rozumiano znacznie szerzej niż dzisiaj - obejmowało ono monastykę (czyli etykę indywidualną), ale także ekonomikę i politykę (Palacz 1978: 16). Można zatem uznać teksty przełożone przez Koszutskiego, Budnego i Petrycego za należące do jednej dziedziny filozoficznej. Co więcej, 
zagadnienia etyczne, a przede wszystkim polityczne i społeczne, należą do głównych problemów przewijających się przez całą historię filozofii polskiej (Krahelska 1967), co nietrudno wyjaśnić najpierw postępującym rozkładem państwa polskiego w okresie przed zaborami, a następnie doświadczeniem zaborów, które sprawiało, że kwestia odzyskania niepodległości i kształtu przyszłego państwa była kluczowa dla polskich myślicieli.

\section{Quomodo?}

Wreszcie pytanie „w jaki sposób?”, które można uznać za najbardziej przekładoznawcze w sensie ścisłym. W niniejszym artykule próba odpowiedzi na nie będzie opierać się na porównaniu tłumaczenia wybranych terminów filozoficznych obecnych w omawianych tekstach, a także zestawieniu najbardziej widocznych elementów strategii translatorskich. Przed przystąpieniem do omówienia polskich przekładów warto jednak zatrzymać się przez chwilę na terminologii grecko-łacińskiej. Autorem wielu łacińskich odpowiedników greckich terminów filozoficznych był nikt inny jak sam Cyceron. Można go uznać za jednego z czołowych twórców łaciny filozoficznej, która w znacznej mierze utrzymała się przez cały okres dominacji tego języka w naukach humanistycznych, tj. przez kolejne kilkanaście wieków. Już u Cycerona można zaobserwować podstawowe strategie terminotwórcze: tworzył rzeczowniki abstrakcyjne na podstawie rzeczowników konkretnych (np. humanitas od homo), nadawał znaczenie filozoficzne wyrazom języka potocznego, czyniąc z nich odpowiedniki greckich terminów (jak w przypadku natura i physis, res publica i polis czy ars i techne), transliterował greckie wyrazy (takie jak logica czy dogma) oraz tworzył kalki na podstawie morfemów składających się na dany termin (np. subiectum będący odpowidnikiem hypokeimenon). Stworzone przez Cycerona ekwiwalencje stały się podstawą łacińskiego języka filozoficznego. Warto tutaj podkreślić, że wykształceni Rzymianie tamtych czasów doskonale znali grekę, jednak zamiarem Cycerona było nie tyle przybliżenie greckich tekstów czytelnikom na Półwyspie Apenińskim, ile „nauczenie filozofii mówienia po łacinie” (Rée 2001: 247). Analogiczną funkcję pełniły pierwsze polskie przekłady Cycerona i Arystotelesa. Warstwy wykształcone znały łacinę (Klemensiewicz 1985: 242; Balcerzan 1984: 55), można zatem przypuszczać, że Koszutskiemu, Budnemu czy Petrycemu również przyświecał cel, by „nauczyć filozofię mówienia po polsku”. 
W pierwszym polskim przekładzie O powinnościach Cycerona uderza objętość tekstu. Tłumacz nie tylko dodał nieistniejące w oryginale podrozdziały, ale również znacznie wydłużył tekst, stosując rozwinięte peryfrazy lub też kilka wyrazów na przełożenie jednego. I tak animantium omni to „wszelakie żywe stworzenie tak rozumne jako bezrozumne", aequabile et temperatum orationis genus to „mowie spokoyney a skromnej, mierney i śrzedniey” (w przekładzie Wiktora Kornatowskiego z 1960 roku „łagodny i poważny sposób przemawiania”), pulchritudo, constantia, ordo to „piękność, przystoyność, stałość, a porządek”, causae to „początki i przyczyny”, veri investigatio to "dochodzenie, albo wynaydowanie rzeczy prawdziwych a gruntownych", verus to "grunt a prawda”, scientiae cupiditas to „chuć ku wiadomości i ku naukom”, turpitudo to „sromota a lekkość” (we współczesnym przekładzie „haniebność”), imperio to „państwo a zwierzchność”, principium urbis to "początek miasta albo Państwa”, peregrinorum to „cudzoziemcom albo przychodniom”, a aries (taran) to „działa albo insze wojenne naczynie”.

Przekład traktatu Cycerona O przyjaźni autorstwa Bieniasza Budnego również jest znacząco dłuższy od oryginału, jednak tłumacz w mniejszym stopniu zastosował podwajanie ekwiwalentów. Tym, co rzuca się w oczy przy lekturze tego tekstu, są zapożyczenia. W przeciwieństwie do Koszutskiego Budny często stosował wyrazy pochodzące z łaciny lub innych języków romańskich, przy czym najczęściej nie są one związane z leksemami obecnymi w tekście źródłowym. Nie jest to zaskakujące, biorąc pod uwagę rosnący wpływ łaciny na polszczyznę owej epoki (Klemensiewicz 1985: 339). I tak in amici mutua benevolentia conquiescat to "przyjaciela, z którego był kontent, wzajem sobie chęć uprzejmą pokazując". Fragment o Grekach brzmiący $\mathrm{w}$ oryginale ut iis ponatur, de quo disputent quamvis subito to u Budnego „Propozycja dana, o czymby differować mieli, tedy zaraz nic nie myśląc o tym diskurrują" - ani 'differować, ani 'diskurrować' nie pochodzą bezpośrednio od obecnego w tekście czasownika disputare, nie figurują też w Słowniku polszczyzny XVI wieku (1966-2011), jednak dyszkurować (rozprawiać) można znaleźć wśród zapożyczeń z łaciny doby średniopolskiej wymienianych przez Zenona Klemensiewicza (1985:340). Nieco dalej przy admiratio czytamy „będąc dobrej existimaciey o mnie”, a milites gloriosi to „wykonterfetowani chłopi chlubni”. Słownik polszczyzny XVI wieku notuje czasowniki 'ekstymować' oraz 'kontrefetować', a zatem tłumacz nie odbiegał nadmiernie od norm swojej epoki. Pomimo licznych egzotyzacji większość tekstu przełożona jest za pomocą rodzimych odpowiedników. Niekiedy 
nawet można zaobserwować elementy strategii udomowienia ${ }^{3}$, jak w przypadku wyliczenia Paulos, Catones, Gallos, Scipiones, Philos, które w polskim przekładzie brzmi „Pawły, Gawły, Katony, Scypiony i Filuse”.

Znacznie mniej makaronizmów można zaobserwować w przekładach Sebastiana Petrycego. Z kolei pochodzenie tłumacza widać w pojawiających się w jego przekładach bohemizmach, takich jak pochop (pojętność, zrozumienie) (Basaj, Siatkowski 2006: 234). Terminologię filozoficzną obecną w tekście Etyki nikomachejskiej szczegółowo opisała Izabela Winiarska (1994). Charakterystyczne dla przekładów Petrycego są stosowane przez niego neologizmy. W Etyce pojawiają się m.in. takie przymiotniki jak 'przespiecznobuczni' (nadmiernie ufający w swoją odwagę), 'podłomyślny' (zbyt nisko ceniący się), 'nadergniewliwi' (za bardzo gniewający się) czy 'kwaśnogniewliwi' (tłumiący gniew w sobie, od acerbus) (Winiarska 1994: 133), w Polityce zaś można znaleźć a takie neologizmy jak 'spolchleboieyce' (towarzysze stołu) czy 'spoldymni' (towarzysze ogniska), przy czym po każdym z nich następuje również tłumaczenie opisowe. Mimo że przytoczone tutaj wyrażenia nie należą do domeny filozoficznej, warto zwrócić uwagę na procesy słowotwórcze, które odpowiadają mechanizmom tworzenia leksyki filozoficznej poprzez zestawienie różnych morfemów w jednym wyrazie. Poza tym Petrycy, podobnie jak Koszutski, stosował serie możliwych ekwiwalentów na przełożenie jednego terminu źródłowego, np. optimates

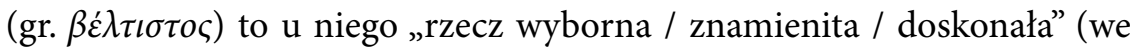
współczesnym przekładzie Polityki:,doskonałośc’). Warto również zwrócić uwagę na konkretność terminologii filozoficznej Petrycego w porównaniu ze współczesnymi przekładami: tam, gdzie dzisiaj czytamy o „właściwości” lub „charakterze”, u Petrycego jest „rzecz”, „poprzez doświadczenie” to u niego „z potocznych rzeczy”, a człowiek „górujący cnotą” jest po prostu „lepszy”4. Tłumacz umieścił także przypisy, w których wyjaśnił niektóre decyzje translatorskie. Na przykład wyrażenie „grubi ludzie” (współcześnie „barbarzyńcy”) opatrzone jest przypisem „grubym rozumiem człowieka prostego". Ponadto po każdym rozdziale tłumacz dodał swoje „Dokłady” lub „Przestrogi”, a w tekście Polityki umieścił również obszerne wyjaśnienia w nawiasach kwadratowych, których objętość jest porównywalna z objęto-

3 Na temat strategii udomowienia i wyobcowania por. m.in. Venuti 1995.

4 Tendencję do używania rzeczowników abstrakcyjnych w miejsce konkretnych można zaobserwować w wielu współczesnych przekładach, co krytykuje m.in. jeden z czołowych francuskich przekładoznawców Henri Meschonnic (1999). 
ścią samego tekstu Arystotelesa. Przykładem może być wyjaśnienie metafory mieczy delfickich, które zawsze mają jeden cel, a nie wiele. Po przetłumaczonym zdaniu w nawiasie czytamy, że ,także też tu natura obraca niewiastę do rodzenia, nie do służenia; sługę zaś obraca do służenia, nie do rodzenia. A tak te dwie społecznośći nie mogą bydź iedna”. Paratekst tłumacza jest u Petrycego tak rozbudowany, że według Jacka Jadackiego Przydatki do „Etyki” Arystotelesowej należy uznać za pierwszy tekst filozoficzny pisany w języku polskim (Jadacki 2015: 12).

We wszystkich analizowanych przekładach można zaobserwować strategie stosowane już przez Cycerona. W zależności od przekładu strategie neologii semantycznej, transliteracji, kalki czy neologii strukturalnej stosowane są w różnym stopniu przez wszystkich tłumaczy, przy czym zdecydowanie najczęściej mamy do czynienia z neologią semantyczną, czyli nadaniem nowego znaczenia wyrazowi już wcześniej obecnemu w ówczesnej polszczyźnie (Polański 2003: 392).

\section{Cui bono?}

Podsumowując, wypada odpowiedzieć na ostatnie pytanie D’hulsta: kto korzystał $\mathrm{z}$ omawianych przekładów? Barbara Topolska w swoim artykule na temat czytelnictwa w Wielkim Księstwie Litewskim pisze, że „rola książki w dobie odrodzenia i baroku była znacznie większa niż zwykliśmy sądzić" ze względu na słabość innych czynników kulturotwórczych - np. kazania Piotra Skargi po łacinie były czytane przez cały polski kler (Topolska 1979: 203, 228). Wydawane przez Jana Karcana przekłady Cycerona również cieszyły się dużą popularnością, o czym świadczą cztery wydania O powinnościach oraz trzy wydania $O$ starości i $O$ przyjaźni. Popularność przekładów Cycerona utrzymała się także przez kolejne stulecia. Glosy i podpisy osób ze stanu mieszczańskiego i szlacheckiego świadczą o „żywym stosunku czytelników XVII- i XVIII-wiecznych do tego rodzaju literatury" (Topolska 1980: 252-253). Wydawane w Krakowie przekłady Arystotelesa również doczekały się kolejnych wydań, co świadczy o ich popularności, przy czym należy pamiętać, że w drugiej połowie XVI wieku czytać potrafili jedynie przedstawiciele patrycjatu, i to nie wszyscy, a około 80\% (Andrzejewska 1997-2018). Omawiane przekłady nie trafiały zatem „pod strzechy”, jednak z pewnością miały duży wpływ na kształtowanie się zarówno polskiej kultury, jak i języka 
filozoficznego. Mimo że wiele terminów przytaczanych powyżej odbiega od dzisiejszego uzusu, inne używane są do dzisiaj, a przekłady te są czytelne dla współczesnego czytelnika.

\section{Literatura}

Andrzejewska J., 1997-2018, Czytelnictwo, [w:] Encyklopedia PWN, https://encyklopedia.pwn.pl/haslo/czytelnictwo;4007934.html (dostęp: 30.04.2021).

Aristoteles, 1605, Polityki Aristotelesowey to iest rządu Rzeczypospolitey z dokładem ksiąg ośmioro, tłum. S. Petrycy, Kraków.

Aristoteles, 1618a, Ethyki Aristotelesowey to iest iako sie każdy ma na świecie rządzić z dokładem ksiąg dziesięciorga, tłum. S. Petrycy, Kraków.

Aristoteles, 1618b, Oekonomiki Aristotelesowey to iest rządu domowego z dokładem księgi dwoje, tłum. S. Petrycy, Kraków.

Aristoteles, 1894, Aristotle's Ethica Nicomachea, Oxford, http://www.perseus.tufts. edu/hopper/text?doc=urn:cts:greekLit:tlg0086.tlg010.perseus-grc1 (dostęp: 30.04.2021).

Aristoteles, 1935, Aristotle in 23 Volumes. Volume 18, Cambridge, http://www. perseus.tufts.edu/hopper/text?doc=urn:cts:greekLit:tlg0086.tlg029.perseus-grc1 (dostęp: 30.04.2021).

Aristoteles, 1957, Aristotle's Politica, Oxford, http://www.perseus.tufts.edu/hopper/ text?doc=urn:cts:greekLit:tlg0086.tlg035.perseus-grc1 (dostęp: 30.04.2021).

Aristoteles, 1964, Polityka z dodaniem Pseudo-Arystotelesowskiej Ekonomiki, tłum. L. Piotrowicz, Warszawa.

Aristoteles, 1982, Etyka nikomachejska, tłum. D. Gromska, Warszawa.

Balcerzan E. (red.), 1984, Wielojęzyczność literatury i problem przekładu artystycznego, Wrocław.

Ballard M., 2013, Histoire de la traduction, Bruxelles.

Basaj M., Siatkowski J. (red.), 2006, Bohemizmy w języku polskim: słownik, Warszawa.

Bąk S. et al., 1966-2011, Słownik polszczyzny XVI wieku, Wrocław.

Bogucka M., 1991, Dzieje kultury polskiej do 1918 roku, Wrocław.

Bończa Bukowski de P., Heydel M., 2013, Polska myśl przekładoznawcza, [w:] Polska myśl przekładoznawcza: antologia, P. de Bończa Bukowski, M. Heydel (red.), Kraków, s. 7-37.

Brückner A., 1958, Dzieje kultury polskiej, t. 3, Warszawa.

Chevrel Y., Cointre A., Tran-Gervat Y.-M. (red.), 2014, Histoire des traductions en langue française. XVIIe et XVIIIe siècles, Paris. 
Chevrel Y., D’hulst L., Lombez C. (red.), 2012, Histoire des traductions en langue française. XIXe siècle (1815-1914), Paris.

Chevrel Y., Masson J.-Y., 2012, Avant-propos, [w:] Histoire des traductions en langue française. XIXe siècle (1815-1914), Y. Chevrel, L. D’hulst, C. Lombez (red.), Paris.

Cicero M.T., 1593, O powinnościach, tłum. S. Koszutski, Wilno [przedruk 1766, Wilno].

Cicero M.T., 1603, Rozmowa o przyjaźni, tłum. B. Budny, Wilno [przedruk 1805, Połock].

Cicero M.T., 1884, Laelius de amicitia, Leipzig, http://www.forumromanum.org/ literature/cicero/amic.html (dostęp: 30.04.2021).

Cicero M.T., 1913, De officiis. With an English Translation, Cambridge, http://www. perseus.tufts.edu/hopper/text?doc=urn:cts:latinLit:phi0474.phi055.perseus-eng1 (dostęp: 30.04.2021).

Cicero M.T., 1960, O państwie; O prawach; O powinnościach; O cnotach, tłum. W. Kornatowski, Warszawa.

Cicero M.T., 1963, O starości; O przyjaźni; Topiki; Fragmenty, tłum. W. Kornatowski, Warszawa.

Delisle J., Woodsworth J. (red.), 2012, Translators through history. Revised Edition, Amsterdam.

D’hulst L., 2014, Essais d'histoire de la traduction. Avatars de Janus, Paris.

Duché V. (red.), 2015, Histoire des traductions en langue française. XVe et XVIe siècles, Paris.

Jadacki J., 2015, Polish Philosophy of the 19th and 20th Centuries. Heritage Studies, Warszawa.

Kamper-Warejko J., 2017, Polski XVI-wieczny przekład poradnika Piotra Krescencjusza jako świadectwo przenikania kultur, „Rocznik Przekładoznawczy. Studia nad Teorią, Praktyką i Dydaktyką Przekładu”, 12, s. 153-169.

Kędelska E., Kwilecka I., Łuczak A., 1999-2012, Słownik Bartłomieja z Bydgoszczy, Warszawa.

Klemensiewicz Z., 1985, Historia języka polskiego II, Warszawa.

Krahelska H. (red.), 1967, Filozofia polska, Warszawa.

Ladmiral J.-R., 2017, Le tournant philosophique dans la traduction. Wykład wygłoszony na konferencji „Traduction et philosophie”, Liège.

Le Blanc C., 2019, Histoire naturelle de la traduction, Paris.

Legeżyńska A., 1986, Tłumacz i jego kompetencje autorskie: na materiale powojennych tłumaczeń poezji A. Puszkina, W. Majakowskiego, I. Kryłowa i A. Błoka, Warszawa.

Lelewel J., 1823, Bibliograficznych ksiąg dwoje, t. 1, Wilno. 
Meschonnic H., 1999, Poétique d'un texte de philosophe et de ses traductions: Humboldt, Sur la tâche de l'écrivain de l'histoire, [w:] H. Meschonnic, Poétique du traduire, Paris.

Palacz R., 1978, Nauczanie filozofii na Uniwersytecie Krakowskim, [w:] Nauczanie filozofii w Polsce w XV-XVIII wieku, L. Szczucki (red.), Wrocław, s. 7-85.

Polański K. (red.), 2003, Encyklopedia językoznawstwa ogólnego, Wrocław.

Pym A., 1998, Method in Translation History, Manchester.

Pym A., 2009, Humanizing Translation History, „Hermes - Journal of Language and Communication Studies", 42, s. 23-48.

Rée J., 2001, The Translation of Philosophy, „New Literary History”, 32, nr 2, s. 223-257.

Reynolds M., 2018, Literatura w historii (i historii przekładów), tłum. Z. Ziemann, „Przekładaniec”, 36, s. 7-24.

Sadkowski W., 2013, Odpowiednie dać słowu słowo, Toruń.

Skrzydlewski P., 2010, Ekonomika, [w:] Powszechna encyklopedia filozofii, A. Maryniarczyk (red.), Lublin, http://www.ptta.pl/pef/pdf/e/ekonomika.pdf (dostęp: 30.04.2021).

Soliński W., 1987, Przekład artystyczny a kultura literacka: komunikacja i metakomunikacja literacka, Wrocław.

Topolska B.M., 1979, Czytelnictwo książek wydanych na Litwie i Białorusi w XVI i pierwszej połowie XVII wieku, cz. 1, „Pamiętnik Biblioteki Kórnickiej”, 15, s. 204-237.

Topolska B.M., 1980, Czytelnictwo książek wydanych na Litwie i Białorusi w XVI i pierwszej połowie XVII wieku, cz. 2, „Pamiętnik Biblioteki Kórnickiej”, 16, s. 245-274.

Translation Studies Bibliography, https://benjamins.com/online/tsb/ (dostęp: 5.06.2019).

Venuti L., 1995, The Translator's Invisibility, New York.

Winiarska I., 1994, Słownictwo specjalne pierwszego polskiego przekładu Etyki nikomachejskiej Sebastiana Petrycego z Pilzna, [w:] Studia z historii języka polskiego: praca zbiorowa, W. Kupiszewski (red.), Warszawa, s. 122-134.

Ziomek J., 1995, Renesans, Warszawa.

\section{The beginnings of philosophical translation in Poland}

\section{Summary}

The article constitutes an attempt to present some of the oldest translations of philosophy into Polish using the methodology suggested by Lieven D'hulst, based 
on the seemingly simple model: Quis? Quid? Ubi? Quibus auxiliis? Cur? Quomodo? Quando? Cui bono? (Who? What? Where? With whose help? Why? How? When? For whose sake?). In the introduction, the author presents the state of historical research, primarily that in French, and attempts to contextualise in it the study of philosophical translation, understood as non-literary translation. The most important works in historical translation studies are quoted - for example, The History of Translations into French (Histoire des traductions en langue française) - and proposals for Translator Studies are propounded. The latter are compared to the methodology proffered by D'hulst. Next, six works are presented: the first translations of Aristotle and Cicero into Polish. All works discussed date back to the late 16th and early 17th centuries and were published in Łosk (in the Grand Duchy of Lithuania) and Kraków. In accordance with D'hulst's guidelines, the paper places equal emphasis on such elements of analysis as the translators (Quis?) and other people involved in the publishing of the translated works (Quibus auxiliis?), the context in which the translations were created (Ubi? Quando?), and elements of translation strategy (Quomodo?). The latter were studied using the method of comparative analysis of the translators' strategies, mostly in the context of philosophical terms. Elements of domestication and foreignization as well as the presence of the translator's paratext were considered. In the summary the author attempts to briefly answer the question of the influence of these texts on Polish readers (Cui bono?).

Keywords: translation, philosophical translation, history of translation, Cicero, Aristotle, 16th century, 17th century

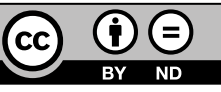

